\title{
APLIKASI PRESENSI PENGENALAN WAJAH DENGAN MENGGUNAKAN ALGORITMA HAAR CASCADE CLASSIFIER
}

\author{
Moh. Wahyu Septyanto(1), Herry Sofyan ${ }^{(2)}$, Herlina Jayadianti( ${ }^{(3)}$, \\ Oliver Samuel $\mathbf{S}^{(4)}$, Dessyanto Boedi $\mathbf{P}^{(5)}$ \\ Jurusan Teknik Informatika Fakultas Teknik Industri UPN "Veteran" Yogyakarta \\ Jl. Babarsari 2 Tambakbayan Yogyakarta \\ e-mail : wseptyanto@gmail.com ${ }^{(1)}$, herrysofyan@gmail.com ${ }^{(2)}$, herlinajayadianti@gmail.com ${ }^{(3)}$
}

\begin{abstract}
Presence using face already widely adopted as a way of monitoring employee attendance. Research on using facial Presence never been done before by applying algorithms and algorithms Eigenface linear discriminant analysis (LDA). However, previous research has found that there are still weaknesses in the algorithms used. The weakness is that the process of identifying which takes a long time because the process of calculating the value carried on the overall image or image and the distance of the face of the webcam can affect the process of identifying faces. In this study, the algorithm used is haar cascade classifier algorithm. Haar classifier cascade or known by other names haar-like features are the rectangular features (square function), which gives an indication of the specifics on a picture or image. Principle Haar-like features are recognizing objects based on simple values of the features but not the pixel values of the object image. This method has the advantage that the computation is very fast, because it depends on the number of pixels in a square instead of each pixel value of an image. Haar classifier cascade also still be able to identify faces even if the distance face with the webcam is considerably due to the value of the facial features can still be identified. Results from this study that the system can identify the face with a good degree of accuracy. Tests carried out to 13 employees Starcross Store with each employee doing 30 times the experiment presence. Attendance successful has the success rate is $87 \%$ and $13 \%$ of the total failure of the experiment 390 times. Some absences failed to happen because there are several factors that can affect attendance as high luminance, uplifted head position, and the use of attributes (hats, glasses, etc.).
\end{abstract}

\section{Keywords : Presence, face recognition, Haar cascade classifier algorithm}

Presensi menggunakan wajah sudah banyak diterapkan sebagai cara untuk pemantauan kehadiran pegawai. Penelitian tentang presensi menggunakan wajah pernah dilakukan sebelumnya dengan menerapkan algoritma eigenface dan algoritma linear discriminant analysis (LDA). Namun dari penelitian sebelumnya telah ditemukan kelemahan yaitu pada proses pengidentifikasian yang membutuhkan waktu cukup lama dikarenakan proses perhitungan nilai dilakukan pada keseluruhan citra atau image dan jauhnya jarak wajah dari webcam dapat mempengaruhi proses pengidentifikasian wajah tersebut. Pada penelitian ini algoritma yang digunakan adalah algoritma haar cascade classifier. Haar cascade classifier atau yang dikenal dengan nama lain haar-like features merupakan rectangular features (fungsi persegi), yang memberikan indikasi secara spesifik pada sebuah gambar atau image. Prinsip Haar-like features adalah mengenali obyek berdasarkan nilai sederhana dari fitur tetapi bukan merupakan nilai piksel dari image obyek tersebut. Metode ini memiliki kelebihan yaitu komputasinya sangat cepat, karena hanya bergantung pada jumlah piksel dalam persegi bukan setiap nilai piksel dari sebuah image. Haar cascade classifier juga masih dapat mengidentifikasi wajah walaupun jarak wajah dengan webcam terbilang jauh dikarenakan nilai fitur wajah masih dapat diidentifikasi. Hasil dari penelitian ini bahwa sistem dapat mengidentifikasi wajah dengan tingkat akurasi baik. Pengujian dilakukan kepada 13 karyawan Starcross Store dengan masingmasing karyawan melakukan 30 kali percobaan presensi. Absensi yang berhasil memiliki nilai keberhasilan $87 \%$ dan $13 \%$ gagal dari total percobaan 390 kali. Beberapa absensi yang gagal terjadi karena ada beberapa faktor yang dapat mempengaruhi absensi seperti pencahayaan yang tinggi, posisi kepala yang mendongkak dan penggunaan atribut (topi, kacamata, dsb).

Kata Kunci : Presensi, Pengenalan Wajah, Algoritma Haar Cascade Classifier 


\section{PENDAHULUAN}

Penelitian absensi menggunakan pengenalan wajah dilakukan untuk mengganti sistem absensi sebelumnya karena fingerprint masih memiliki beberapa kelemahan seperti sulitnya pengidentifikasian jari jika kondisi jari terkelupas, berminyak dan celah untuk melakukan manipulasi sidikjari antar pengguna. Absensi pengenalan wajah juga telah dilakukan dengan menggunakan metode eigenface, template matching dan algoritma linear discriminant analysis (LDA) yang juga masih memiliki kelemahan pada proses pengidentifikasian.

Dari beberapa kelemahan fingerprint yang ada dan metode-metode pengenalan wajah yang digunakan pada penelitian sebelumnya, maka penelitian berfokus pada sistem absensi menggunakan pengenalan wajah dengan menerapkan algoritma haar cascade classifier. Haar cascade classifier atau yang dikenal dengan nama lain haar-like features merupakan rectangular features (fungsi persegi), yang memberikan indikasi secara spesifik pada sebuah gambar atau image. Prinsip Haar-like features adalah mengenali obyek berdasarkan nilai sederhana dari fitur tetapi bukan merupakan nilai piksel dari image obyek tersebut. Metode ini memiliki kelebihan yaitu komputasinya sangat cepat, karena hanya bergantung pada jumlah piksel dalam persegi bukan setiap nilai piksel dari sebuah image. (Viola \& Jones, 2001). Dari penjelasan algoritma yang digunakan, haar cascade classifier memiliki prinsip atau kelebihan yang tidak dimiliki oleh metode yang telah digunakan pada penelitian sebelumnya. Diharapkan sistem absensi pegawai menggunakan pengenalan wajah dengan menerapkan algoritma haar cascade classifier dapat mengurangi masalah yang ada di sistem absensi menggunakan fingerprint dan dapat melengkapi kekurangan yang ada pada metode yang telah digunakan sebelumnya.

Penelitian pertama yang menggunakan sidik jari dilakukan oleh Rintjap (Rintjap, Sompie, \& Lantang, 2014) dengan judul Aplikasi absensi siswa menggunakan sidik jari di sekolah menengah atas negeri 9 manado. Rinjtap menggunakan sidik jari untuk sistem kehadiran siswa dan masih memiliki kekurangan yaitu jika tidak menggunakan alat fingerprint yang berkualitas tinggi maka kemampuan sistem dalam membaca sidik jari terbilang kurang baik. Hal ini dapat mempengaruhi apabila jari pengguna yang sedang dalam masalah seperti basah karena keringat. Penelitian kedua yang menggunakan sidik jari dilakukan oleh Gandhi (Gandhi, 2017) dengan judul Penerapan absensi fingerprint dalam mendisiplinkan kerja pegawai di sekolah mengah kejuruan (SMK) sekolah menengah tekhnik industri (SMTI) bandar lampung. Gandhi menggunakan sidik jari untuk sistem kehadiran pegawai kekurangannya adalah untuk pegawai yang memiliki jari yang sensitif maupun pegawai yang jarinya terkadang basah karena keringat masih menimbulkan masalah dalam pendeteksian jari pegawai tersebut. Penelitian ketiga yang menggunakan sidik jari dilakukan oleh Putra (Putra, 2018) dengan judul Sistem absensi mahasiswa menggunakan fingerprint $U$ Are U 4500 pada STMIK AMIK Riau. Dari hasil penelitian tersebut, Putra memaparkan bahwa penelitian yang lakukan terdapat masalah yaitu jika jari mahasiswa yang ingin melakukan absensi dalam kondisi berkeringat atau basah dapat mempengaruhi proses pendeteksian.

Penelitian pertama yang menggunakan pengenalan wajah dilakukan oleh Puri (Puri, 2011) dengan judul Analisis algoritma eigenface (pengenalan wajah) pada aplikasi kehadiran pengajaran dosen. Puri menggunakan eigenface dalam aplikasi kehadiran dosen menggunakan pengenalan wajah kekurangannya adalah jika pencahayaan yang terlalu tinggi maka dapat mengurangi keakuratan pengenalan wajah. Penelitian kedua yang menggunakan pengenalan wajah dilakukan oleh Rahman (Rahman \& Wasista, 2010) dengan judul Sistem pengenalan wajah menggunakan webcam untuk absensi dengan metode template matching. Rahman menggunakan metode template matching dengan menggabungkan dua metode lainnya yaitu eucledian distance dan eigenface dengan hasil penelitian yaitu jika citra memiliki tingkat pencahayaan yang tinggi maka sistem akan error karena hasil capture yang kurang jelas. Penelitian ketiga yang menggunakan pengenalan wajah dilakukan oleh Iskandar (Iskandar, Kom, \& MM, 2013) dengan judul Penerapan algoritma linear discriminant analysis (LDA) untuk pengenalan wajah sebagai pemantau kehadiran karyawan. Iskandar menggunakan algoritma linear discriminant analysis (LDA) masih memiliki kekurangan yaitu proses perhitungan nilai dilakukan pada keseluruhan citra atau image, hal ini bisa menimbulkan proses tersebut akan memakan waktu cukup lama. Penelitian keempat yang menggunakan pengenalan wajah 
dilakukan oleh Laswi (Laswi \& Zainuddin, 2016) dengan judul Implementasi algoritma linear discriminant analysis (LDA) untuk sistem absensi berbasis pengenalan wajah. Pada penelitian yang dilakukan oleh Laswi masih terdapat beberapa kekurangan yaitu terjadinya pendeteksian yang error jika citra yang diuji memiliki pencahayaan yang berbeda, pose dan atribut tambahan lainnya yang digunakan oleh pengguna.

\section{METODOLOGI PENELITIAN}

Algoritma yang digunakan mampu mengenali wajah yang telah tersimpan di database dengan citra masukkan pada saat melakukan presensi. Apabila citra wajah yang tersimpan di database dengan citra masukkan teridentifikasi sama maka absensi berhasil.

\subsection{Proses Pengolahan Data}

Pre-processing

Pada tahap pre-processing dilakukan pengubahan citra berwarna menjadi citra berskala abuabu (grayscale) untuk menjadi inputan selanjutnya dalam haar cascade classifier. Grayscale merupakan proses yang terjadi pada saat melakukan presensi, proses awal yang dilakukan yaitu pemanggilan data pengguna yang dimana data citra akan langsung diproses untuk pengubahan ke skala abu-abu.

\section{Deteksi wajah}

Pada proses ini dilakukan beberapa tahap pokok sehingga menghasilkan hasil akhir berupa wajah yang terdeteksi sama. Berikut langkah-langkah pendeteksian wajah menggunakan haarcascade classifier.

\section{Haar like feature}

Metode ini menggunakan haar-like features dimana perlu dilakukan training terlebih dahulu untuk mendapatkan suatu pohon keputusan dengan nama cascade classifier sebagai penentu apakah ada obyek atau tidak dalam tiap frame yang diproses. Ada tiga macam fitur yang digunakan yaitu edge features, line features dan four-rectangle features disajikan pada gambar 1 sebagai berikut:

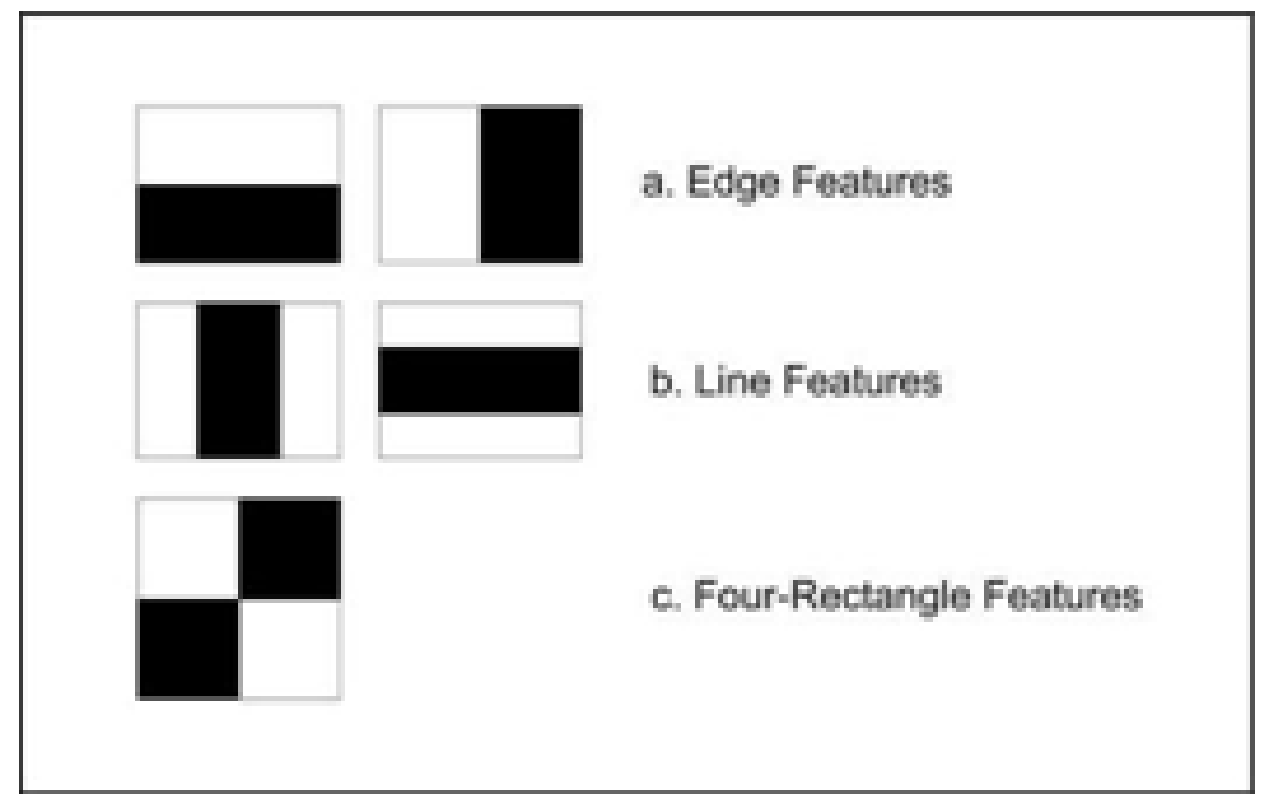

Gambar 1. Haar-like features

Nilai Haar Like Feature diperoleh dari selisih jumlah nilai piksel daerah gelap dengan jumlah nilai piksel daerah terang sebagai berikut : 


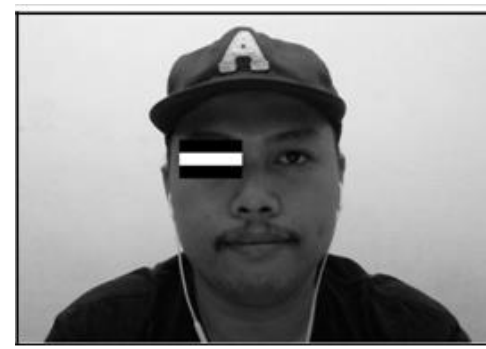

$F$ Haar $=\sum F_{\text {white }}-\sum F_{\text {black }}$

\section{Gambar 2. Contoh haar-like feature pada sebuah citra}

Keterangan:

$F$ Haar = Nilai fitur total

$\sum F_{\text {white }}=$ Nllai fitur pada daerah terang

$\sum F_{\text {black }}=$ Nilai fitur pada daerah gelap

\subsection{Integral Image}

Citra integral adalah citra yang nilai tiap pixel-nya merupakan akumulasi dari nilai pixel atas dan kirinya. Integral Image yaitu suatu teknik untuk menghitung nilai fitur secara cepat dengan mengubah nilai dari setiap piksel menjadi suatu representasi citra baru. Sebagai contoh, pixel $(a, b)$ memiliki nilai akumulatif untuk semua pixel $(x, y)$ dimana $x \leq a$ dan $y \leq b$.

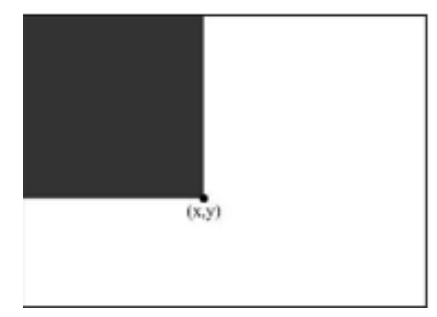

Gambar 3. Integral image $(x, y)$

Berdasarkan gambar 3 citra integral pada titik $(x, y)$, nilai $(i i(x, y))$ dapat dicari menggunakan persamaan 2.

$i i(x, y)=\sum_{x^{\prime} \leq y^{\prime} \leq y^{\prime}} i\left(x^{\prime}, y^{\prime}\right)$

Dimana $i i(x, y)$ adalah citra integral dan $i(x, y)$ adalah citra asli dengan kondisi :

$i i(x, y)=i(x, y)+i i(x-1, y)+i i(x, y-1)-i i(x-1, y-1)$

Perhitungan nilai dari suatu fitur dapat dilakukan secara cepat dengan menghitung nilai citra integral pada empat buah titik sebagaimana disajikan dalam gambar 2 .

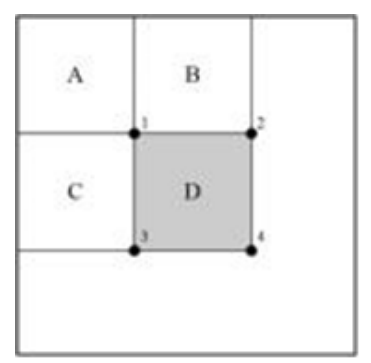

\section{Gambar 4. Perhitungan nilai fitur}


Jika nilai integral image titik 1 adalah $A$, titik 2 adalah $A+B$, titik 3 adalah $A+C$, dan di titiki 4 adalah $A+B+C+D$, maka jumlah piksel di daerah $D$ dapat diketahui dengan cara $4+1-(2+3)$.

\subsection{Adaboost Learning}

Algoritma Adaboost learning, digunakan untuk meningkatkan kinerja klasifikasi dengan pembelajaran sederhana untuk menggabungkan banyak classifier lemah menjadi satu classifier kuat. Classifier lemah adalah suatu jawaban benar dengan tingkat kebenaran yang kurang akurat. Sebuah classifier lemah dinyatakan pada persamaan 4.

$h_{j}(x)=\left\{\begin{array}{l}1, \text { jika } p_{J} f_{J}<p_{J} \theta_{J}(x) \\ 0, \\ \text { lainnya }\end{array}\right.$

Keterangan:

$h_{i}(x)$ adalah klasifikasi lemah, $p_{I}$ adalah parity ke j, $\theta_{i}$ adalah threshold ke $\mathrm{j}$ dan $\mathrm{x}$ adalah dimensi sub image misalnya $24 \times 24$.

Langkah-langkah untuk mendapatkan sebuah classifier kuat dinyatakan dalam suatu algoritma sebagai berikut:

a. Diberikan contoh gambar $\left(x_{1}, y_{1}\right), \ldots\left(x_{n}, y_{n}\right)$ dimana $y_{i}=0$ untuk contoh positif dan $y_{i}=1$ untuk contoh negative.

b. Inisialisasi bobot $y_{i, 1}=\frac{1}{2 m}, \frac{1}{2 l}$; m dan I adalah jumlah negatif dan positif.

c. Untuk $t=1, \ldots, T$

Menormalisasikan bobot sehingga $w_{t}$ adalah distribusi probabilitas.

$w_{t, i} \leftarrow \frac{w_{t, i}}{\sum_{j=1}^{n} w_{t, j}}$

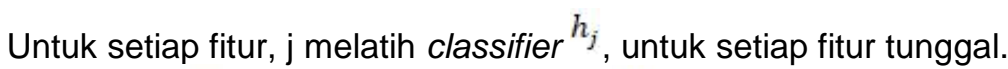

Kesalahan ${ }^{e_{j}}$ dievaluasi dengan bobot $w_{t}$

$e_{j}=\sum_{i} w_{i}\left|h_{j}\left(x_{i}\right)-y_{i}\right|$

Pilih classifier $h_{t}$ dengan eror terkecil dimana $e_{i}=0$ untuk $x_{i}$ adalah klaifikasi benar, dan $e_{i}=1$ untuk yang lain.

Perbaharui bobot:

$w_{t+1, i}=w_{t, i} \beta_{t}^{1-\theta_{i}}$

$\operatorname{dimana} \beta_{t}=\frac{e_{t}}{1-e_{t}}$

Didapatkan sebuah Classifier kuat yaitu :

$h(x)= \begin{cases}1, \sum_{t=1}^{T} \alpha_{t} h_{t}(x) \geq \frac{1}{2} \sum_{t=1}^{T} \alpha_{t} \\ 0, & \text { lainnya }\end{cases}$

dimana $\alpha_{t}=\log \frac{1}{\beta_{t}}$

\subsection{Cascade Classifier}

Cascade classifier melakukan proses penyaringan subcitra dengan membentuk tingkatan penyaringan berdasarkan banyak fitur yang ditentukan oleh adaboost. Terdapat beberapa tingakatan klasifikasi untuk menentukan apakah benar atau tidak ada fitur objek wajah pada fitur yang sudah dipilih. Pada saat klasifikasi bagian subcitra akan melalui beberapa tahapan penyaringan dimana pada tahap awal subcitra yang tidak menggandung objek wajah akan ditolak dan sedangkan untuk subcitra yang menggandung objek positif akan dijadikan inputan pada tahapan penyaringan berikutnya hingga didapatkan sub-citra yang diyakini sebagai objek wajah. 


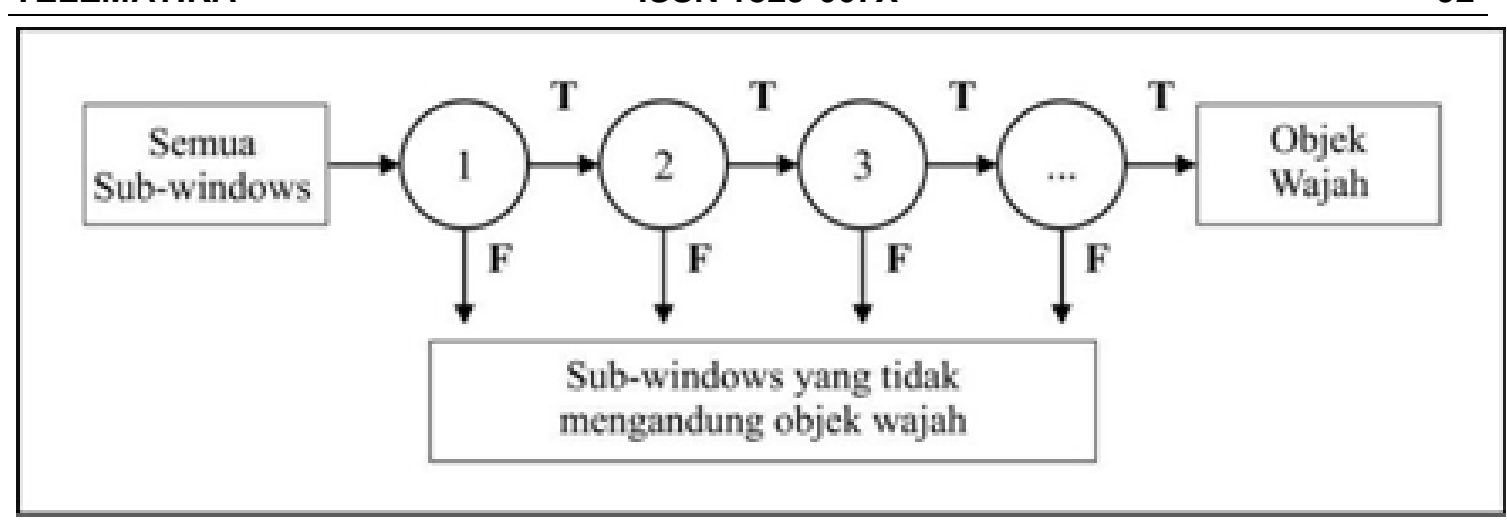

\section{Gambar 5. Cascade Classifier}

Pada klasifikasi filter pertama, tiap subcitra akan diklasifikasi menggunakan satu fitur. Jika hasil nilai fitur dari filter tidak memenuhi kriteria yang diinginkan, maka hasil ditolak. Algoritma kemudian bergerak ke sub window selanjutnya dan menghitung nilai fitur kembali. Jika didapat hasil sesuai dengan threshold yang diinginkan, maka dilanjutkan ke tahap filter selanjutnya. Hingga jumlah sub window yang lolos klasifikasi pun akan berkurang hingga mendekati citra yang ada pada sampel. Sepertia gambar 5 diatas, dapat dijelaskan secara keseluruhan proses cascade classifier-nya sebagai berikut :

1. Filter pertama

a) 1 fitur

b) Detection rate : $100 \%$, false positive rate : $50 \%$

2. Filter kedua

a) 5 fitur

b) Detection rate : $100 \%$, false positive rate : $80 \%$

3. Filter ketiga dan keempat

a) 20 fitur

Setelah dilakukan serangkain proses seperti pemilihan fitur dan klasifikasi bertingkat maka akan didapatkan sebuah hasil pendeteksian. Hasil pendeteksian berupa objek wajah. Pada saat proses klasifikasi bertingkat dilakukan maka, pada bagian subcitra tersebut akan ditandai dengan sebuah detector yang ditentukan pada daerah subwindow objek wajah yang terdeteksi dan apabila tidak ada objek wajah tedeteksi maka, image tersebut tidak akan ditandai oleh sebuah detector.

Berikut contoh hasil fitur yang mengandung objek wajah dan ditandai dengan sebuah detector disajikan pada gambar 6 .

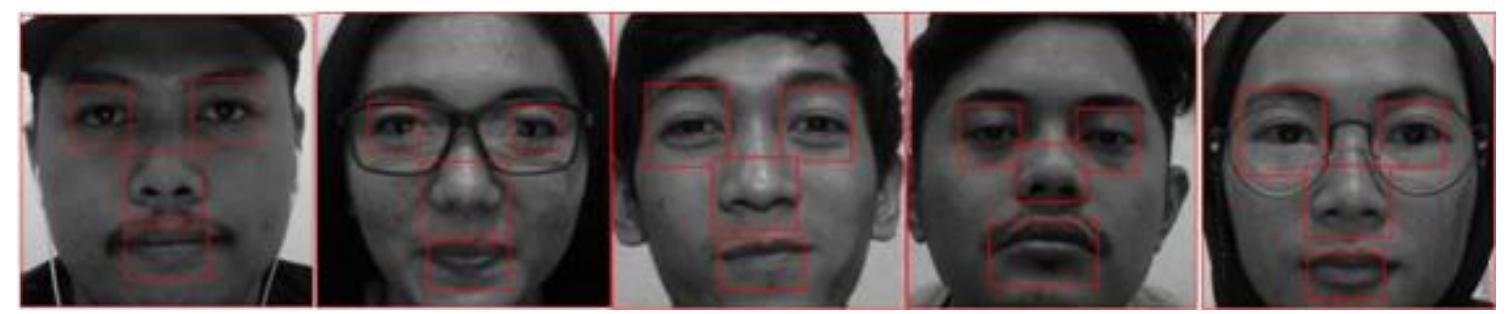

Gambar 6. Contoh Pendeteksian Wajah Haar Cascade Classifier 


\section{HASIL DAN PEMBAHASAN}

Pada bagian ini dipaparkan hasil pengujian kesesuaian data yang dapat menjelaskan kondisi apa saja yang dapat mempengaruhi terdeteksinya wajah atau tidak terdeteksinya wajah dan pembahasan tentang algoritma haar cascade classifier.

\subsection{Hasil Pengujian Data}

Pada bagian ini dilakukan pengujian kepada pegawai dengan melakukan ujicoba kepada masing-masing pegawai sebanyak 30 kali ujicoba presensi. Berikut disajikan pengujian data pada tabel 1.

Tabel 1. Hasil Pengujian Data

\begin{tabular}{|c|c|c|c|c|}
\hline \multirow[b]{2}{*}{ No } & \multirow[b]{2}{*}{ Data Pengzuna } & \multicolumn{2}{|c|}{ Wajah Terdetekai } & \multirow[b]{2}{*}{ Keterangan } \\
\hline & & Wajah Sama & $\begin{array}{c}\text { Wajah Tidak } \\
\text { Sama }\end{array}$ & \\
\hline 1 & $\begin{array}{l}\text { Nik: } 001 \\
\text { Nama : Walyo }\end{array}$ & $25 \mathrm{kali}$ & 5 kali & 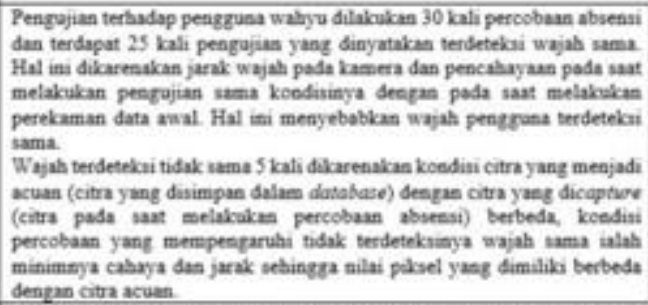 \\
\hline 2 & $\begin{array}{l}\text { Nik : } 002 \\
\text { Nama : Wike }\end{array}$ & 26 kah & 4 kali & 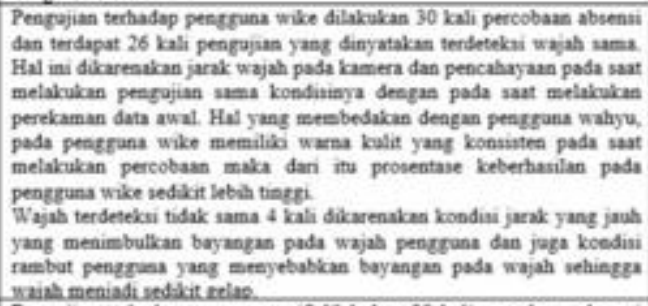 \\
\hline 3 & $\begin{array}{l}\text { Nik: } 003 \\
\text { Nama : Anif }\end{array}$ & $28 \mathrm{kah}$ & 2 kali & 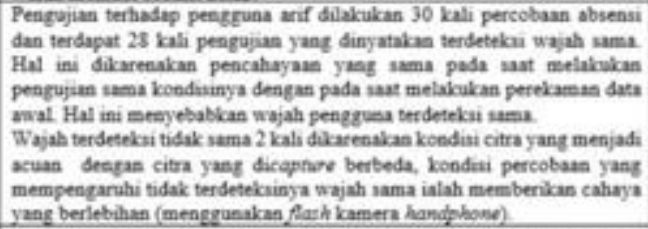 \\
\hline 4 & $\begin{array}{l}\text { Nik: } 004 \\
\text { Nama : Luthe }\end{array}$ & 26 kalis & 4 kati & 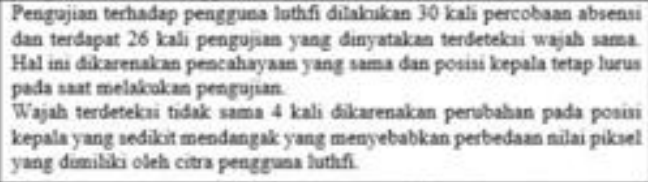 \\
\hline 5 & $\begin{array}{l}\text { Nik: } 005 \\
\text { Nima : Siwi }\end{array}$ & 27 kals & 3 kali & 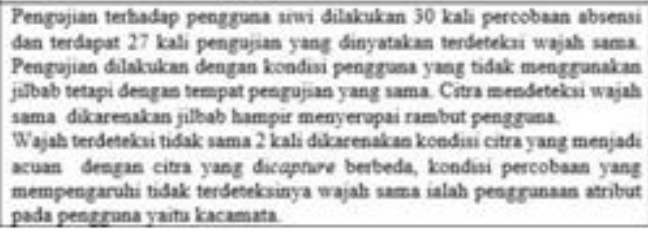 \\
\hline
\end{tabular}

Dari tabel pengujian data tersebut, dapat ditarik kesimpulan bahwa aplikasi presensi pengenalan wajah yang telah dibuat memiliki beberapa masalah pada kondisi wajah pada saat melakukan absensi yang menjadikan aplikasi masih tidak dapat membaca wajah walaupun menggunakan wajah yang sama. Masalah-masalah yang dimaksud ialah kondisi wajah yang mendongkak, pada pengujian yang dilakukan kepada 13 pegawai yang terkait beberapa wajah pegawai tidak dapat terdeteksi. Hal ini dikarenakan daerah wajah pegawai tersebut memiliki banyak daerah gelap yang mengakibatkan nilai piksel dari citra sangatlah besar dan pada saat dilakukan pencocokan, citra tersebut memiliki nilai rasio yang tinggi dan citra dianggap tidak sama. Kondisi yang ketiga yaitu penambahan pencahayaan, pada pengujian yang telah dilakukan kondisi pencahayaan menjadi salah satu faktor berpengaruhnya pada keakuratan dikarenakan cahaya dapat mempengaruhi nilai piksel yang ada sehingga wajah sehingga tidak dapat terdeteksi. Kondisi yang ketiga yaitu penambahan atribut, atribut yang dimaksud ialah 
seperti penggunaan topi, kacamata, penggunaan makeup, jilbab dan sebagainya. Kondisi ini juga menjadi salah satu faktor yang berpengaruh yang membuat aplikasi sulit dalam pencocokkan wajah. Atribut seperti topi bisa menghasilkan bayangan pada daerah wajah pengguna yang menjadikan nilai piksel yang ada menjadi tinggi dan pencocokkan menjadi kurang akurat dikarenakan nilai rasio tidak sama atau lebih dari yang telah ditentukan.

\subsection{Pengujian Kondisi}

Pada tahap ini pengujian dilakukan dengan menguji beberapa kondisi yang menurut peneliti menjadi hal yang penting untuk diperhatikan dan dapat mempengaruhi proses pengenalan wajah pada aplikasi ini. Berikut disajikan pengujian kondisi pada tabel 2.

Tabel 2. Hasil Pengujian Kesesuaian Data

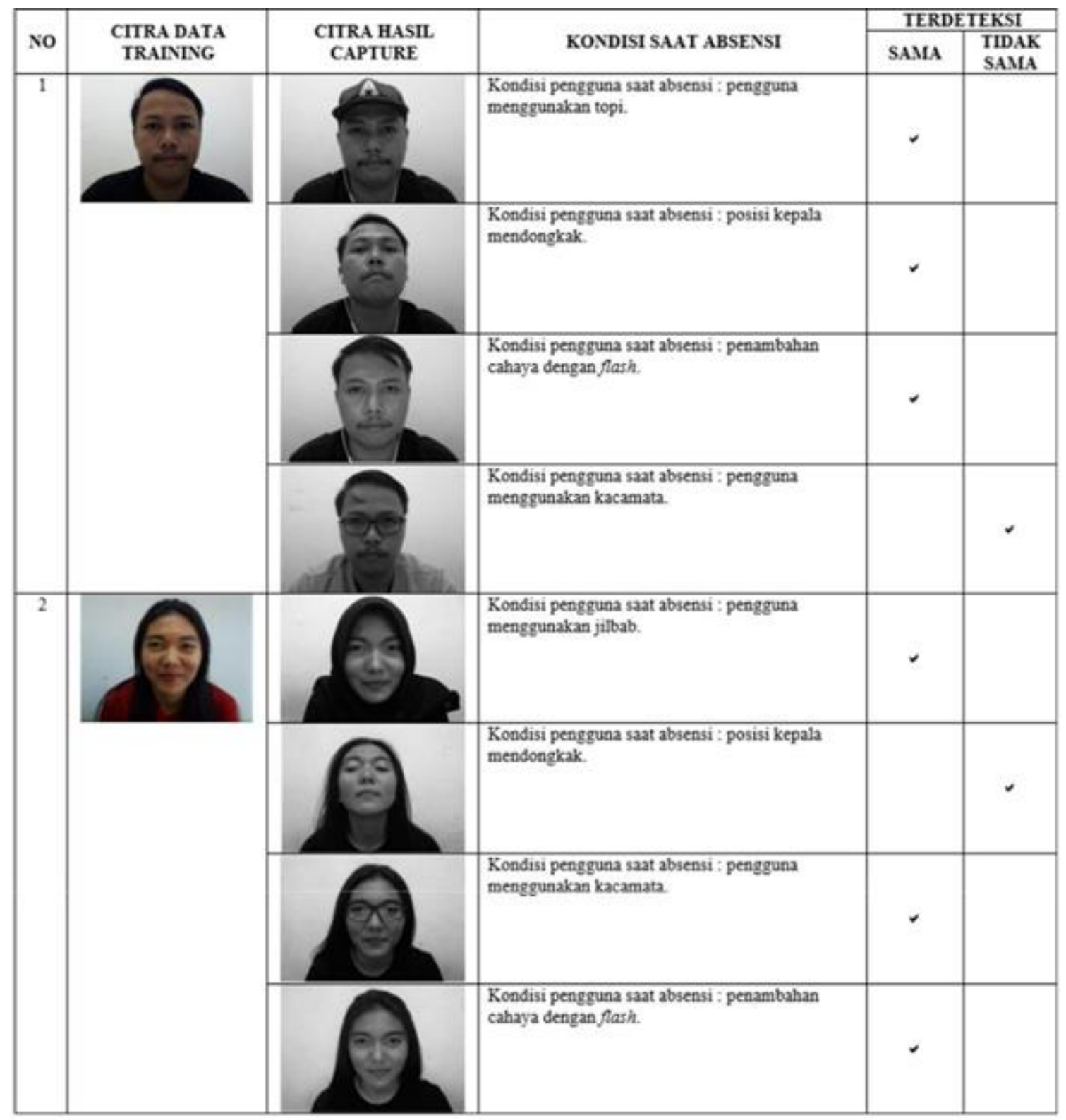


Tabel 3. Lanjutan Hasil Pengujian Kesesuaian Data

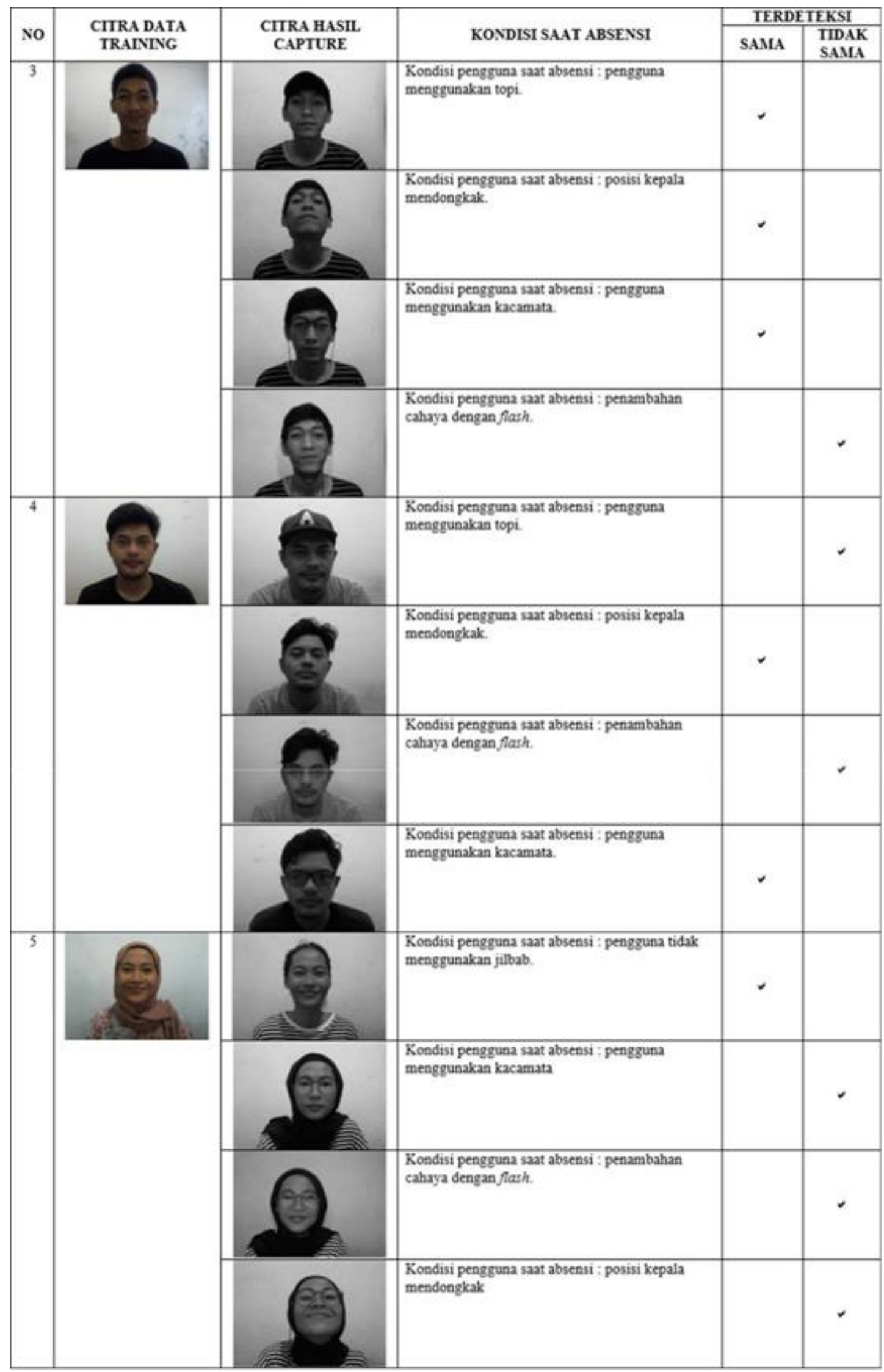


Berdasarkan pada penelitian yang telah dilakukan terhadap aplikasi pengenalan wajah dengan menggunakan algoritma haar cascade classifier (studi kasus : starcross store) maka dapat diambil kesimpulan sebagai berikut :

1. Aplikasi ini telah berhasil mengurangi celah untuk melakukan kecurangan pada sistem absensi pegawai.

2. Berdasarkan hasil pengujian, aplikasi ini masih memiliki kekurangan pada pencahayaan. Apabila cahaya pada citra yang menjadi acuan sedikit berbeda dengan citra yang dicapture secara realtime maka wajah tidak dapat dikenali dan aplikasi ini masih dapat mengenali lebih dari satu objek wajah.

Beberapa hal yang disarankan dalam pengembangan aplikasi pengenalan wajah di starcross clothing menggunakan algoritma haar cascade classifier ini adalah sebagai berikut :

1. Aplikasi ini dapat dikembangkan lagi dengan menggabungkan algoritma lainnya agar aplikasi ini bisa lebih optimal dalam melakukan pengenalan dan pencocokkan wajah yang lebih akurat.

2. Penggunaan aplikasi ini masih dalama berbentuk desktop, penulis menyarankan untuk kedepannya dapat dikembangkan kedalam aplikasi berbasis mobile.

3. Pengembangan aplikasi ini dapat dilakukan pada proses presensi, dimana pengguna tanpa harus menginputkan data terlebih dahulu agar dapat mengefisiensikan waktu presensi tersebut

\section{DAFTAR PUSTAKA}

Gandhi, M. A. (2017). Penerapan Absensi Finger Print Dalam Mendisiplinkan Kerja Pegawai Di Sekolah Menengah Kejurujan (SMK) Sekolah Menengah Tekhnik Industri (SMTI) Bandar Lampung (PhD Thesis). UIN Raden Intan Lampung.

Iskandar, R. J., Kom, S., \& MM, M. (2013). Penerapan Algoritma Linear Discriminant Analysis (LDA) Untuk Pengenalan Wajah Sebagai Pemantau Kehadiran Karyawan. KATA PENGANTAR, 81.

Laswi, A. S., \& Zainuddin, Z. (2016). Implementasi Algoritma LDA Untuk Sistem Absensi Berbasis Pengenalan Wajah. JURNAL IT: Media Infromasi STMIK Handayani Makassar, 7(2), 108-115.

Puri, F. T. (2011). Analisis algoritma eigenface (pengenalan wajah) pada aplikasi kehadiran pengajaran dosen.

Putra, J. R. K. (2018). Sistem Absensi Mahasiswa Menggunakan Finger Print U Are U 4500 pada STMIK AMIK RIAU. Jaringan Sistem Informasi Robotik-JSR, 2(1), 75-80.

Rahman, M., \& Wasista, S. (2010). Sistem pengenalan wajah menggunakan webcam untuk absensi dengan metode template matching. EEPIS Final Project.

Rintjap, A. S., Sompie, S. R., \& Lantang, O. (2014). Aplikasi Absensi Siswa Menggunakan Sidik Jari di Sekolah Menengah Atas Negeri 9 Manado. Jurnal Teknik Elektro Dan Komputer, 3(3), 1-5.

Viola, P., \& Jones, M. (2001). Rapid object detection using a boosted cascade of simple features. Null, 511. IEEE. 